\title{
THE ROLE OF GENERAL HEALTH ADVISORY BOARD \\ IN MUHAMMADIYAH GAMPING HOSPITAL, YOGYAKARTA, WITHIN THE ACADEMIC HEALTH CENTER CONCEPT
}

\author{
Tiara Tresnantia, Arlina Dewi, Ekorini Listiowati
}

Masters Program in Hospital Management, Universitas Muhammadiyah Yogyakarta

\begin{abstract}
Background: Academic Health Center (AHC) is a concept that combines education, research and health services functions. Muhammadiyah is a Muslim organization in Indonesia with a wide range of business sections, including health education and health care provision. The General Health Advisory Council (MPKU) is a policy maker and advisor for the hospital and primary health care facilities. This study aimed to analyze the role of MPKU within the AHC concept at Muhammadiyah Gamping Hospital, Yogyakarta.

Subjects and Method: This was a qualitative study carried out at Muhammadiyah Gamping Hospital and Faculty of Medicine and Health Sciences Universitas Muhammadiyah Yogyakarta (FKIK UMY), from May to June 2018. A sample of 5 informants was selected for this study, consisting of representatives from MPKU and Muhammadiyah Gamping Hospital. The data were collected by in-depth interview.

Results: Within the AHC concept, the General Health Advisory Council Muhammadiyah (MKPU) had an important role as a policy maker and advisor for the hospital and primary health care facilities. MPKU Muhammadiyah had just reached the legal stage of collaboration and coordination with FKIK UMY and $\mathrm{Mu}-$ hammadiyah Gamping Hospital to realize the concept of AHC. Muhammadiyah Gamping Hospital had the important role of performing clinical hospital and referral services. The Faculty of Medicine and Health Sciences Universitas Muhammadiyah Yogyakarta (FKIK UMY) had three important roles: (1) managing the medical education to produce medical doctors and allied health professionals; (2) conducting health research; (3) community development.

Conclusion: MPKU Muhammadiyah has just reached the legal stage of collaboration and coordination with FKIK UMY and Muhammadiyah Gamping Hospital to realize the concept of AHC.
\end{abstract}

Keywords: General Health Advisory Council Muhammadiyah, Academic Health Center, Faculty of Medicine and Health Sciences, hospital.

\section{Correspondence:}

Tiara Tresnantia. Masters Program in Hospital Management, Universitas Muhammadiyah Yogyakarta, Jl. Lingkar Selatan, Tamantirto, Kasihan, Bantul, Yogyakarta 55183. Email: tiara.tresnantia@gmail.com. Mobile: o8121500040 